\title{
Effects of an HMG-CoA Reductase Inhibitor in Combination with an ACE Inhibitor or Angiotensin II Type 1 Receptor Antagonist on Myocardial Metabolism in Ischemic Rabbit Hearts
}

\author{
Hitoshi KAWABATA, Kizuku NAKAGAWA, and Kinji ISHIKAWA
}

\begin{abstract}
We investigated the effects of a 3-hydroxy-3-methylglutaryl coenzyme A (HMG-CoA) reductase inhibitor, pravastatin, an angiotensin converting enzyme (ACE) inhibitor, temocaprilat, and an angiotensin II type 1 (AT1) receptor antagonist, CV-11974, on myocardial metabolism during ischemia in isolated rabbit hearts using phosphorus 31-nuclear magnetic resonance ( $\left.{ }^{31} \mathrm{P}-\mathrm{NMR}\right)$ imaging. Forty-five minutes of continuous normothermic global ischemia was carried out. Pravastatin, temocaprilat, CV-11974 or a nitric oxide synthase inhibitor, L-NAME was administered from $60 \mathrm{~min}$ prior to the global ischemia. Japanese white rabbits were divided into the following experimental groups, a control group $(n=7)$, a group treated with pravastatin $(P$ group; $n=7$ ), a group treated with pravastatin and temocaprilat $(P+T$ group; $n=7)$, a group treated with pravastatin and CV-11974 ( + CV group; $n=7)$, and a group treated with pravastatin and L-NAME $(P+L-$ NAME group; $\boldsymbol{n}=7$ ). During ischemia, $\mathbf{P}$ group, as well as either $\mathbf{P}+\mathbf{T}$ group or $\mathbf{P}+\mathbf{C V}$ group, showed a significant inhibition of the decreases in adenosine triphosphate (ATP) and intracellular $\mathrm{pH}(\mathrm{pHi})(p<0.01$, respectively, at the end of ischemia compared to the control group as well as P + L-NAME group), and a significant inhibition of the increase in inorganic phosphate $(\mathrm{Pi})(p<0.01$, respectively, compared with the control group as well as $\mathrm{P}+\mathrm{L}-\mathrm{NAME}$ group). These results suggest that pravastatin significantly improved myocardial energy metabolism during myocardial ischemia. This beneficial effect was dependent on NO synthase. However, this beneficial effect was not enhanced by either temocaprilat or CV-11974.
\end{abstract}

(Hypertens Res 2002; 25: 203-210)

Key Words: HMG-CoA reductase inhibitor, angiotensin converting enzyme inhibitor, angiotensin II receptor antagonist, cardioprotection, ischemia

\section{Introduction}

Clinical trials have shown that 3-hydroxy-3-methylglutaryl coenzyme A (HMG-CoA) reductase inhibitors such as pravastatin reduce myocardial infarction and ischemic stroke (1-3). Recent studies have suggested that HMG-CoA reductase inhibitors activate endothelial nitric oxide synthase (eNOS) independently of its effects on lipids $(4,5)$. The renin-angiotensin system (RAS) is activated upon acute myo- cardial infarction in both humans (6) and experimental animals $(7,8)$. In dogs, localized angiotensin II (Ang II) has been shown to exert some deleterious effects on the myocardium of the ischemia-reperfused heart (9). Angiotensin converting enzyme (ACE) inhibitors protect the myocardium from ischemia and reperfusion injury $(10,11)$. Ang II type 1 (AT1) receptor antagonists also exert cardioprotective effects against ischemia-reperfusion injury (12). We have also shown that the combination of an ACE inhibitor and AT1 receptor antagonist can help protect against ischemia-reperfu-

From the First Department of Internal Medicine, Kinki University School of Medicine, Osakasayama, Japan.

Address for Reprints: Hitoshi Kawabata, M.D., First Department of Internal Medicine, Kinki University School of Medicine, 377-2 Ohno-Higashi,

Osakasayama 589-8511, Japan. E-mail: int1@med.kindai.ac.jp

Received August 20, 2001; Accepted in revised form December 6, 2001. 
sion injury in rabbit hearts (13). While ACE inhibitors have been shown to activate bradykinin, bradykinin enhances accumulation of endothelial nitric oxide (NO)/cyclic GMP (14). In addition, although the actions of Ang II are mainly mediated via two types of receptors (15), known as AT1 and AT2 receptors, increased AT2 receptor expression in myocardial infarction has been observed (16). Thus the functions of the AT2 receptor in ischemia-reperfusion injury have been shown to include stimulation of NO production (17). Additional mechanisms that may play a role in ischemia-reperfusion injury include the reduction in myocardial damage by an HMG-CoA reductase inhibitor, reduced formation of Ang II, or activation of eNOS. However, it has not been clearly determined whether or not HMG-CoA reductase inhibitors administered in combination with an ACE inhibitor or AT1 receptor antagonist exert cardioprotective effects against myocardial ischemia-reperfusion injury. The purpose of the present study was to determine whether combination of a HMG-CoA reductase inhibitor and ACE inhibitor or AT1 receptor antagonist serves as a potentiation or not of the cardioprotective effect in the ischemic heart and to search for possible action of these agents, which suggests future clinical applications. Accordingly, we here used phosphorus 31-nuclear magnetic resonance $\left({ }^{31} \mathrm{P}-\mathrm{NMR}\right.$ spectroscopy) imaging of myocardial energy metabolism to investigate whether the above combination treatments would potentiate the cardioprotective effect in ischemic, isolated rabbit hearts, and if so, what their possible mechanisms might be. The administration of $\mathrm{HMG}-\mathrm{CoA}$ reductase inhibitor alone, as well as in combination with either an ACE inhibitor or AT1 receptor antagonist, was found to improve abnormal myocardial energy metabolism. These data suggest that this beneficial effect was not dependent on either the production of NO synthase of the reduced formation of Ang II induced by either the ACE inhibitor or AT1 receptor antagonist.

\section{Materials and Methods}

\section{Experimental Protocol}

The hearts were divided into the following 7 groups: 1) a control group injected intravenously with vehicle (physiologic saline) at $60 \mathrm{~min}$ prior to global ischemia (C group; $n=7)$; 2) a group injected intravenously with pravastatin (Sankyo Co., Tokyo, Japan) $(0.025 \mathrm{mg} / \mathrm{kg}$ ) at $60 \mathrm{~min}$ prior to global ischemia (P group; $n=7)$; 3 ) a group injected intravenously with temocaprilat (Sankyo Co.) $(0.027 \mathrm{mg} / \mathrm{kg}$ ) at 60 min prior to global ischemia (T group; $n=7)$; 4) a group injected intravenously with CV-11974 (Takeda Chemical Industries, Ltd., Osaka, Japan) $(0.025 \mathrm{mg} / \mathrm{kg})$ at $60 \mathrm{~min}$ prior to global ischemia (CV group; $n=7)$; 5) a group injected intravenously with pravastatin $(0.025 \mathrm{mg} / \mathrm{kg})$ coupled with temocaprilat $(0.027 \mathrm{mg} / \mathrm{kg})$ at $60 \mathrm{~min}$ prior to global ischemia (P + T group; $n=7)$; 6) a group injected intravenously with pravastatin $(0.025 \mathrm{mg} / \mathrm{kg})$ coupled with $\mathrm{CV}-11974$
$(0.025 \mathrm{mg} / \mathrm{kg})$ at $60 \mathrm{~min}$ prior to global ischemia $(\mathrm{P}+\mathrm{CV}$ group; $n=7)$; and 7) a group injected intravenously with pravastatin $(0.025 \mathrm{mg} / \mathrm{kg})$ coupled with $N^{\mathrm{G}}$-nitro-L-arginine methyl ester (L-NAME) (Sigma Chemical Co., St. Louis, USA) $(1.5 \mathrm{mg} / \mathrm{kg})$ at $60 \mathrm{~min}$ prior to global ischemia $(\mathrm{P}+\mathrm{L}-$ NAME group; $n=7)$. This dose of pravastatin, temocaprilat and CV-11974 is necessary to obtain a relevant pharmacological concentration in situ such as $10^{-6} \mathrm{M}$. This high dose of L-NAME is necessary to inhibit cardiovascular NO synthase. After $60 \mathrm{~min}$ of treatment, continuous normothermic global ischemia was induced by severing the aorta and removing the heart.

\section{Isolated Heart Preparation}

All procedures were in accordance with the guidelines for animal research at our institution. Male Japanese white rabbits weighing 1.6 to $1.7 \mathrm{~kg}$ were anesthetized by intravenous injection of sodium pentobarbital $(30 \mathrm{mg} / \mathrm{kg})$. An endotracheal tube was inserted, and the lungs were ventilated with room air supplemented with $95 \%$ oxygen. The chest was opened and heparin sodium $(1,000 \mathrm{IU} / \mathrm{kg})$ was injected through the right atrial appendage. The heart was quickly removed and immediately mounted on a ${ }^{31} \mathrm{P}-\mathrm{NMR}$ device, and then measurement of ${ }^{31} \mathrm{P}-\mathrm{NMR}$ spectra was initiated.

\section{Measurements of High Energy Phosphates and Intra- cellular $\mathrm{pH}$ by ${ }^{31} \mathrm{P}-\mathrm{NMR}$}

The heart was placed in an NMR sample tube with a diameter of $25 \mathrm{~mm}$ and inserted into a ${ }^{31} \mathrm{P}$ probe. The temperature of the ${ }^{31} \mathrm{P}-\mathrm{NMR}$ device was maintained at $37^{\circ} \mathrm{C}$. The ${ }^{31} \mathrm{P}$ NMR spectra were recorded at $161.9 \mathrm{MHz}$ with $45^{\circ}$ flip-angle pulses at $2.0 \mathrm{~s}$ intervals with a JNM-GX 400 FT NMR spectrometer (JEOL, Tokyo, Japan). Spectra were acquired for $5 \mathrm{~min}$ and averaged from 150 transient samples. Quantitative analysis of the whole heart was performed by the relative intensities of the $\beta$-ATP (adenosine triphosphate) and Pi (inorganic phosphate) peaks. Areas under each peak were integrated five times with a planimeter. The mean of five such readings was normalized as a percentage of the value given during the initial period. The distance of the intracellular Pi peak relative to the intracellular $\mathrm{PCr}$ peak ( $\mathrm{pH}$-independent) was measured and the intracellular $\mathrm{pH}(\mathrm{pHi}$ ) was determined using the following equations $(18): \mathrm{pHi}=\mathrm{p} k-\log _{10}\left[\left(\boldsymbol{\delta}_{0}-\right.\right.$ $\left.\left.\delta_{\mathrm{B}}\right) /\left(\delta_{\mathrm{A}}-\delta_{0}\right)\right], \mathrm{p} k=6.79, \delta_{\mathrm{A}}=3.25, \delta_{\mathrm{B}}=5.75$, where $\delta_{0}$ is the chemical shift of $\mathrm{Pi}$ with respect to $\mathrm{PCr}$.

\section{Statistical Analysis}

Statistical analysis was performed by ANOVA with Tukey's post hoc test. All values were expressed as the mean \pm SD, and levels of $p<0.05$ were considered to indicate statistical significance. 


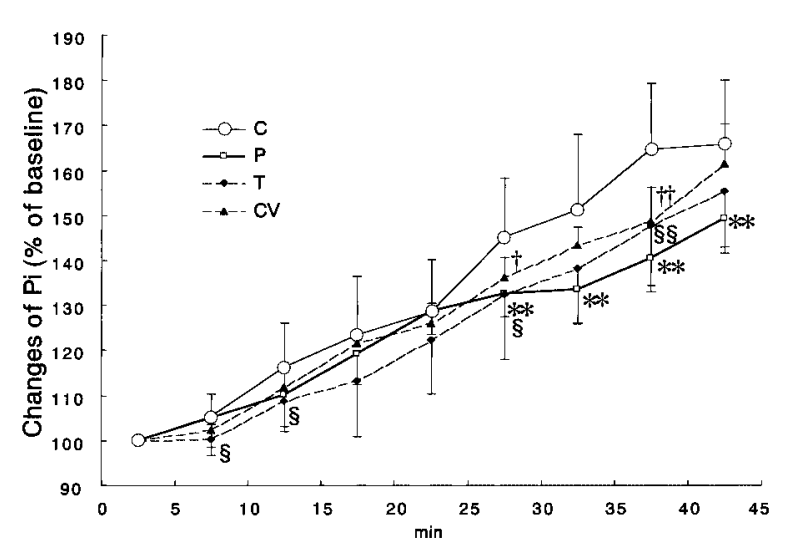

Fig. 1. Changes in Pi in the control group $(C)$, the group treated with $0.025 \mathrm{mg} / \mathrm{kg}$ pravastatin $(P)$, the group treated with $0.027 \mathrm{mg} / \mathrm{kg}$ temocaprilat $(T)$, and the group treated with $0.025 \mathrm{mg} / \mathrm{kg} \mathrm{CV}-11974$ (CV). Data are expressed as the mean $\pm S D .{ }^{* *} \mathrm{p}<0.01$ : P group significantly different from C group. ${ }^{\S} \mathrm{p}<0.05,{ }^{\S} \mathrm{p}<0.01: T$ group significantly different from $C$ group. ${ }^{\dagger} \mathrm{p}<0.05,{ }^{\dagger \dagger} \mathrm{p}<0.01$ : $C V$ group significantly different from $C$ group.

\section{Results}

\section{Metabolic Effect of L-NAME on Isolated Hearts}

L-NAME $(1.5 \mathrm{mg} / \mathrm{kg})$ alone did not affect the metabolism during ischemia (compared with control, all $p=\mathrm{NS}, n=7$ ).

\section{Myocardial Metabolism during Ischemia}

$\mathrm{Pi}$ increased remarkably during ischemia in the $\mathrm{C}$ group (Fig. 1). In contrast, the increase in Pi was inhibited significantly in the $\mathrm{P}$ group $(p<0.01)$ and in portions of the $\mathrm{T}$ and $\mathrm{CV}$ groups $(p<0.05)$ in comparison with that in the $\mathrm{C}$ group. At 42.5 min after the start of ischemia, the Pi values were $166 \pm$ $14,149 \pm 6,155 \pm 14$, and $161 \pm 9 \%$ for the C, P, T, and CV groups, respectively. In the $\mathrm{P}+\mathrm{T}$ and $\mathrm{P}+\mathrm{CV}$ groups, $\mathrm{Pi}$ was significantly $(p<0.01)$ lower than in the $\mathrm{C}$ group during ischemia (Fig. 2). At $42.5 \mathrm{~min}$ after the start of ischemia, the $\mathrm{Pi}$ values were $148 \pm 14$ and $149 \pm 6 \%$ for the $\mathrm{P}+\mathrm{T}$ and $\mathrm{P}+$ $\mathrm{CV}$ groups, respectively. However, there were no statistically significant differences in $\mathrm{Pi}$ between the $\mathrm{P}$ group and either the $\mathrm{P}+\mathrm{T}$ or $\mathrm{P}+\mathrm{CV}$ group during ischemia. In the $\mathrm{P}+\mathrm{L}-$ NAME group, Pi was significantly $(p<0.01)$ higher as well as $\mathrm{C}$ group during ischemia than that in $\mathrm{P}$ group (Fig. 3). At $42.5 \mathrm{~min}$ after the start of ischemia, the value of $\mathrm{Pi}$ was $170 \pm 6 \%$ in the P+L-NAME group. Pi did not show any statistically significant differences between the $\mathrm{C}$ group and P + L-NAME group during ischemia.

During ischemia, ATP gradually declined in the C group (Fig. 4). In contrast, the decrease in ATP was inhibited sig-

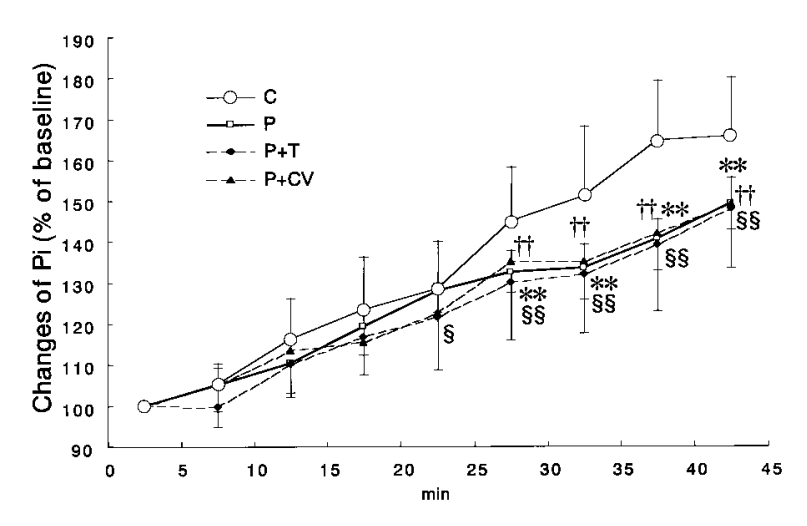

Fig. 2. Changes in Pi in the control group $(C)$, the group treated with $0.025 \mathrm{mg} / \mathrm{kg}$ pravastatin $(P)$, the group treated with $0.025 \mathrm{mg} / \mathrm{kg}$ pravastatin in combination with 0.027 $m g / k g$ temocaprilat $(P+T)$, and the group treated with $0.025 \mathrm{mg} / \mathrm{kg}$ pravastatin in combination with $0.025 \mathrm{mg} / \mathrm{kg}$ $C V-11974(P+C V)$. Data are expressed as the mean \pm SD. ${ }^{* *} \mathrm{p}<0.01$ : P group significantly different from $C$ group. $\S \mathrm{p}<0.05,{ }^{\S} \mathrm{p}<0.01: P+T$ group significantly different from $C$ group. ${ }^{\dagger \dagger} \mathrm{p}<0.01: P+C V$ group significantly different from $C$ group.

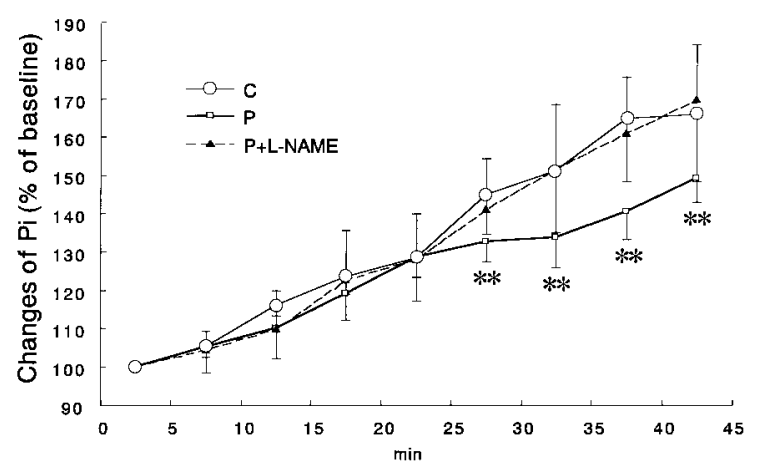

Fig. 3. Changes in Pi in the control $(C)$, the group treated with $0.025 \mathrm{mg} / \mathrm{kg}$ pravastatin $(P)$, and the group treated with $0.025 \mathrm{mg} / \mathrm{kg}$ pravastatin in combination with $1.5 \mathrm{mg} / \mathrm{kg} \mathrm{L}$ NAME $(P+L-N A M E)$. Data are expressed as mean $\pm S D$. ${ }^{* *} \mathrm{p}<0.01$ : $P$ group significantly different from $C$ and $P+L-$ NAME groups.

nificantly in the $\mathrm{P}$ group $(p<0.01)$ and in portions of the $\mathrm{T}$ and $\mathrm{CV}$ groups $(p<0.05)$ in comparison with that in the $\mathrm{C}$ group. Final values at $42.5 \mathrm{~min}$ after the start of ischemia were $42 \pm 12,64 \pm 5,45 \pm 9$, and $53 \pm 5 \%$ for the C, P, T, and $\mathrm{CV}$ groups, respectively. The $\mathrm{P}+\mathrm{T}$ and $\mathrm{P}+\mathrm{CV}$ groups showed a significant $(p<0.01)$ inhibition of the decrease in ATP compared with the $\mathrm{C}$ group (Fig. 5). The final values at $42.5 \mathrm{~min}$ after the start of ischemia were $64 \pm 8$ and $65 \pm 8 \%$ for the $\mathrm{P}+\mathrm{T}$ and $\mathrm{P}+\mathrm{CV}$ groups, respectively. However, there were no differences in ATP between the P group and 


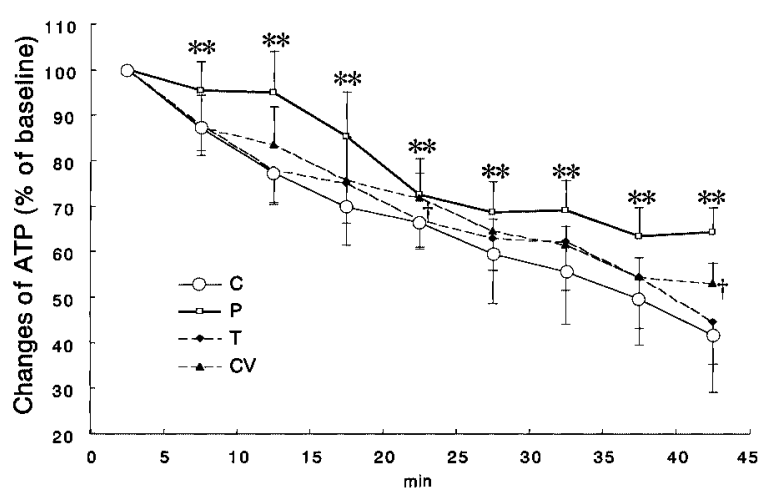

Fig. 4. Changes in ATP in the $C, P, T$, and $C V$ groups. Data are expressed as mean $\pm S D .{ }^{* *} \mathrm{p}<0.01:$ P group significantly different from $C$ group. ${ }^{\dagger} \mathrm{p}<0.05$ : $C V$ group significantly different from $C$ group.

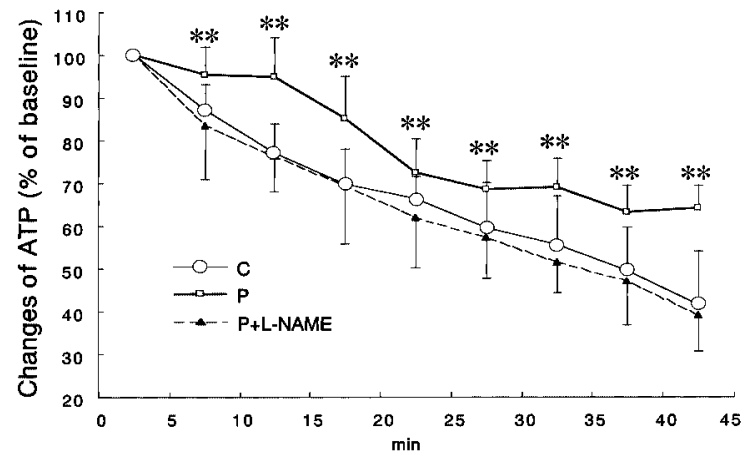

Fig. 6. Changes in ATP in the $C, P$, and $P+L-N A M E$ groups. Data are expressed as mean $\pm S D .{ }^{* *} \mathrm{p}<0.01: P$ group significantly different from $C$ and $P+L-N A M E$ groups.

either the $\mathrm{P}+\mathrm{T}$ or $\mathrm{P}+\mathrm{CV}$ groups at this final time point. In the $\mathrm{P}+\mathrm{L}-\mathrm{NAME}$ group, ATP was significantly $(p<0.01)$ lower as well as $\mathrm{C}$ group during ischemia than that in $\mathrm{P}$ group (Fig. 6). At 42.5 min after the start of ischemia, ATP was $39 \pm 3 \%$ in the $\mathrm{P}+\mathrm{L}-\mathrm{NAME}$ group. There were no significant differences in ATP between the $\mathrm{C}$ group and $\mathrm{P}+\mathrm{L}$ NAME group during ischemia.

pHi dropped sharply, but $\mathrm{pHi}$ remained significantly $(p<$ $0.01)$ higher in the $\mathrm{P}$ group and significantly $(p<0.05)$ higher in portions of the $\mathrm{T}$ group than in the $\mathrm{C}$ group during ischemia (Fig. 7). Finally, at $42.5 \mathrm{~min}$ after the start of ischemia, pHi was significantly $(p<0.01)$ higher in the $\mathrm{P}$ group $(6.43 \pm 0.12)$, but not in either the $\mathrm{T}$ group $(6.16 \pm$ $0.21)$ or CV group (6.11 \pm 0.19$)$, compared with that in the $C$ group $(6.09 \pm 0.11)$. In addition, $\mathrm{pHi}$ remained significantly $(p<0.01)$ higher in the $\mathrm{P}+\mathrm{T}$ and $\mathrm{P}+\mathrm{CV}$ groups than in the $\mathrm{C}$ group (Fig. 8). At the final time point of $42.5 \mathrm{~min}$ after the

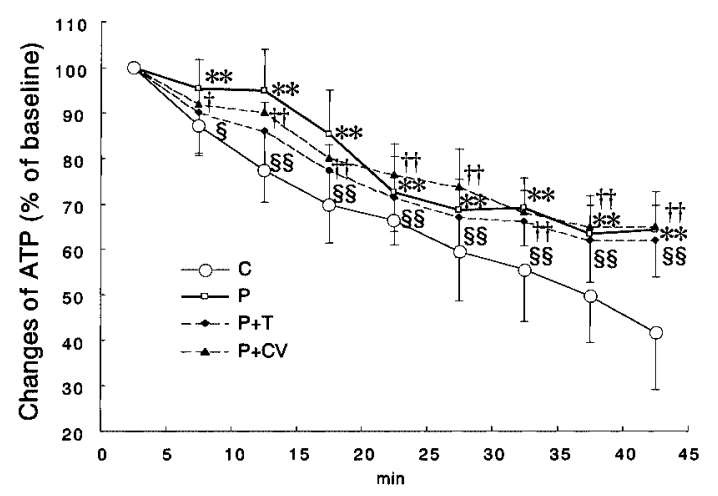

Fig. 5. Changes in ATP in the $C, P, P+T$, and $P+C V$ groups. Data are expressed as mean $\pm S D .{ }^{* *} \mathrm{p}<0.01: P$ group significantly different from $C$ group. ${ }^{\S} \mathrm{p}<0.05$, $\S \mathrm{p}<$ 0.01: $P+T$ group significantly different from $C$ group. ${ }^{\dagger} \mathrm{p}<$ $0.05,{ }^{\dagger \dagger} \mathrm{p}<0.01: P+C V$ group significantly different from C group.

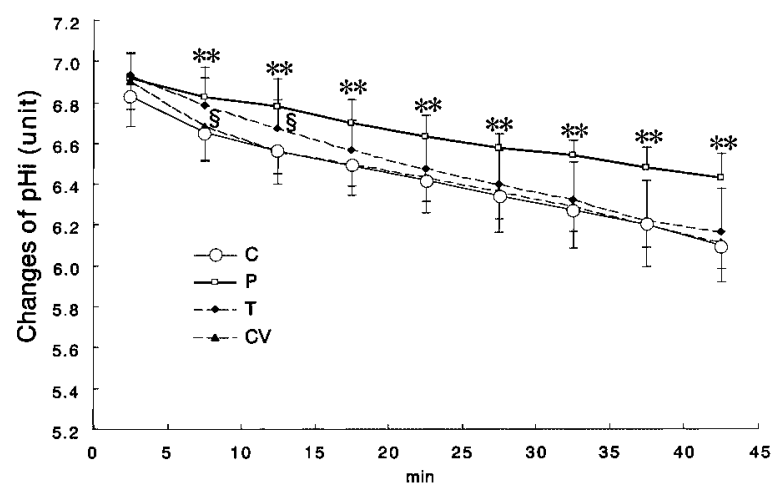

Fig. 7. Changes in pHi in the $C, P, T$, and $C V$ groups. Data are expressed as mean $\pm S D .{ }^{* *} \mathrm{p}<0.01:$ P group significantly different from $C$ group. ${ }^{\S} \mathrm{p}<0.05: T$ group significantly different from $C$ group.

start of ischemia, pHi was significantly $(p<0.01)$ higher in both the $\mathrm{P}+\mathrm{T}(6.36 \pm 0.18)$ and $\mathrm{P}+\mathrm{CV}(6.40 \pm 0.10)$ groups than in the $\mathrm{C}$ group. There were no significant differences in $\mathrm{pHi}$ between the $\mathrm{P}$ group and either the $\mathrm{P}+\mathrm{T}$ or $\mathrm{P}+\mathrm{CV}$ groups during ischemia. In the $\mathrm{P}+\mathrm{L}-\mathrm{NAME}$ group, $\mathrm{pHi}$ was significantly $(p<0.01)$ lower as well as $\mathrm{C}$ group during ischemia than that in $\mathrm{P}$ group (Fig. 9). At 42.5 min after the start of ischemia, pHi was $6.13 \pm 0.04$ in the $\mathrm{P}+\mathrm{L}-\mathrm{NAME}$ group. pHi did not show any statistically significant differences between the $\mathrm{C}$ and $\mathrm{P}+\mathrm{L}-\mathrm{NAME}$ groups during ischemia. 


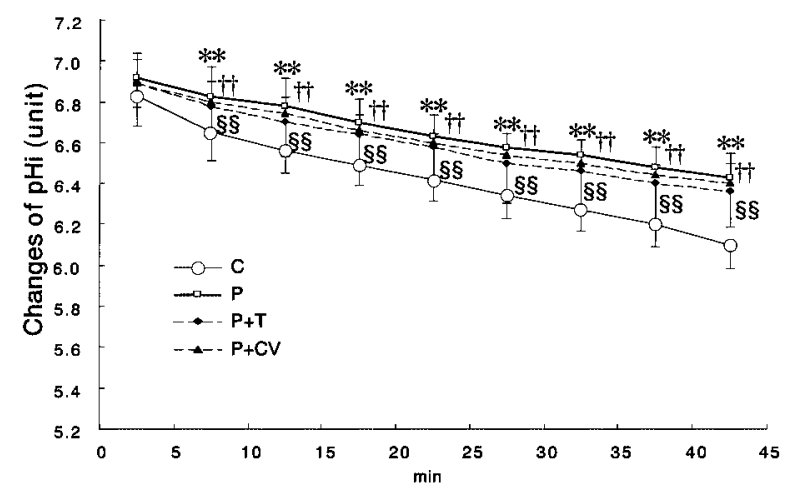

Fig. 8. Changes in $\mathrm{pHi}$ in the $C, P, P+T$, and $P+C V$ groups. Data are expressed as mean $\pm S D .{ }^{* *} \mathrm{p}<0.01: P$ group significantly different from $C$ group. ${ }^{\S} \mathrm{p}<0.01: P+$ $T$ group significantly different from $C$ group. ${ }^{\dagger \dagger} \mathrm{p}<0.01$ : $P+C V$ group significantly different from $C$ group.

\section{Discussion}

We examined whether treatment with an HMG-CoA reductase inhibitor and an ACE inhibitor or an AT1 receptor antagonist significantly improved myocardial injury during ischemia compared with either drug alone. In this experiment, ischemia induced changes of myocardial metabolism, such as decreasing ATP and pHi, and increasing Pi. The decrease of ATP, the fall in pHi, and the elevation of Pi during ischemia were significantly reduced by pravastatin. However, despite the beneficial effects of either temocaprilat alone or CV-11974 alone, there were no significant differences in myocardial metabolism between the group receiving pravastatin alone and the groups receiving pravastatin in combination with temocaprilat or CV-11974. These findings show that pravastatin had a protective effect on myocardial metabolism during ischemia, and that this effect was not enhanced by either temocaprilat or CV-11974. In addition, there were no significant differences in myocardial metabolism during ischemia between the control group and the group receiving pravastatin in combination with L-NAME, despite the beneficial effect of pravastatin alone. These findings show that pravastatin had a protective effect on myocardial metabolism during ischemia, and this effect may have been caused by NO activation.

The overall events in the transition of ischemia to infarction are very complex and cannot simply be related to depletion of ATP (19). Rather, depletion of ATP should be seen as a marker of 1) the severity of the ischemic process; 2) a depressed rate of anaerobic glycolysis in severely ischemic tissue caused by an accumulation of glycolytic end-products; 3 ) inhibited lipid metabolism with accumulation of intermediates such as acyl CoA and acyl carnitine, with inhibition of mitochondrial metabolism; and 4) an accumulation of inter-

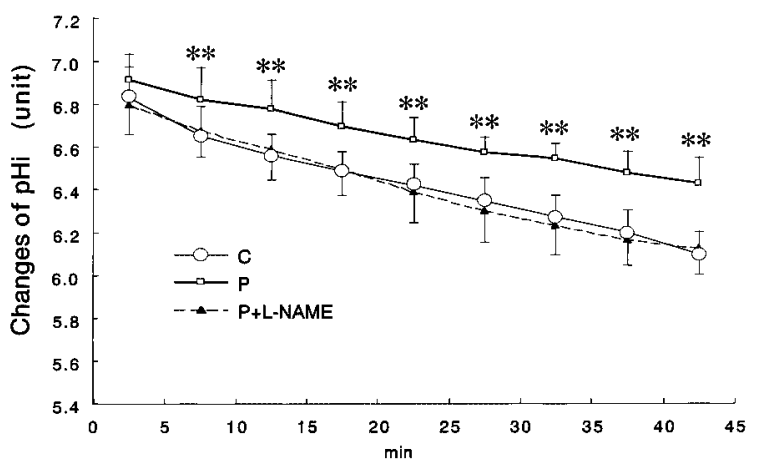

Fig. 9. Changes in $p H i$ in the $C, P$, and $P+L-N A M E$ groups. Data are expressed as mean $\pm S D .{ }^{* *} \mathrm{p}<0.01: P$ group significantly different from $C$ and $P+L-N A M E$ groups.

cellular calcium with ischemic contracture and utilization of ATP. All these processes contribute to damage of the cell membranes (sarcolemma, mitochondria, sarcoplastic reticulum), which is seen as a critical event in irreversible damage (20). As judged by the rate of fall in ATP, many cells in the severely ischemic zone are destined to die soon, within 30-45 min.

Clinical trials with HMG-CoA reductase inhibitors suggest that these inhibitors exert at least part of their cardioprotective action via mechanisms other than simply lowering the lipid load of the vessel wall (21). Several recent studies suggest that HMG-CoA reductase inhibitors increase eNOS activity $(4,22-24)$. And recent studies have provided evidence that endogenous production of NO provides significant myocardial protection from ischemia-reperfusion injury $(25,26)$. HMG-CoA reductase inhibitors increase eNOS expression through an increase in eNOS mRNA stability (23). The study by Kaesemeyer et al.(4) demonstrated that pravastatin stimulated NOS activity and NO release, and that these responses were complete within $10 \mathrm{~min}$. In addition, these authors showed that NO production occurred within the first $30 \mathrm{~min}$ after pravastatin administration. The cardioprotective effects of NO have been explained by several factors, such as microvascular effects (27), antineutrophil action (27), induction of stress protein (28), or modulation of cardiac excitability (29). We found that an HMG-CoA reductase inhibitor exerted a cardioprotective effect on ischemic injury by activating the opening of ATP-sensitive $\mathrm{K}^{+}$(KATP) channels via an NO-mediated pathway (30).

During ischemia, both the ACE inhibitor and AT1 receptor antagonist had a beneficial effect on myocardial metabolism. This reason is that both agents suppress via the Ang II receptor (31). When Ang II binds to the AT1 receptor, which exists in the plasma membrane, cytosolic $\mathrm{Ca}^{2+}$ is increased (32-34). Increase of cytosolic $\mathrm{Ca}^{2+}$ during ischemia may thus be related to the acceleration of ischemic injury. Fur- 
thermore, ACE inhibitors inhibit the degradation of bradykinin, and the increase of bradykinin may have a cardioprotective effect $(35,36)$. And also, two Ang II receptor subtypes, the AT1 and AT2 receptors, have thus far been identified (37). Blockade of the AT1 receptor has been shown to increase the Ang II concentration (38), which may then activate the AT2 receptor $(39,40)$. AT2 receptor activation involve the increase of bradykinin and the subsequent action of prostaglandins and/or NO (41). Recently, we have demonstrated that the cardioprotective effect of combination of ACE inhibitor and AT1 receptor antagonist is not dependent on NO synthase in rabbit cardiac tissue (42). In addition, the cardioprotective effects of AT1 receptor antagonist in the stunned myocardium are provided by activation of $\mathrm{K}_{\text {ATP }}$ channels, which activation is mediated by the bradykinin $\mathrm{B}_{2}$ receptor via AT2 receptor activation (43).

ACE-dependent and -independent (alternate) Ang II-forming pathways also exist in the heart $(44,45)$. We therefore speculated that Ang II antagonists are more effective at protecting against ischemic injury than ACE inhibitors because ACE inhibitors cannot completely inhibit Ang II production (12). But during ischemia, the effect of the Ang II antagonist on myocardial metabolism was the same as that of the ACE inhibitor in our study. One reason is that in rabbits, Ang II is not produced by chymase (46), and thus ACE may be the main Ang II-forming pathway in rabbit hearts. Another reason is that when the AT1 receptor antagonist binds to the AT1 receptor, ACE activity is increased by feedback regulation (47). Therefore, ACE inhibitor inhibits Ang II production due to the increase of ACE activity.

In the present study, administration of HMG-CoA reductase inhibitor alone was more effective against ischemic injury than administration of either ACE inhibitor or AT1 receptor antagonist alone. The results suggest that the enhancement of NO release by HMG-CoA reductase inhibitor may have played a more important role than reduction of Ang II forms by either ACE inhibitor or AT1 receptor antagonist during ischemia. Furthermore, the protective effect of the combination of $\mathrm{HMG}-\mathrm{CoA}$ reductase inhibitor with either ACE inhibitor or AT1 receptor antagonist did not result in a significant improvement in myocardial metabolism against ischemic injury compared to that by HMG-CoA reductase inhibitor alone. This may be because the HMG-CoA reductase inhibitor induced a more complete release of NO than either the ACE inhibitor or AT1 receptor antagonist in rabbit cardiac tissue.

In conclusion, dual-therapy with pravastatin and either temocaprilat or CV-11974 did not produce additive reduction in ischemic injury of rabbit hearts compared with HMGCoA reductase inhibitor alone, and it was suggested that ischemic injury cannot be retarded beyond the level achieved with monotherapy of HMG-CoA reductase inhibitor.

\section{Limitations of the Study}

Our studies were performed in rabbit hearts; results may differ in human hearts. The present study did not directly reveal the mechanism by which suppression of Ang II availability and increased bioavailability of NO in tissue inhibits ischemic injury.

\section{Conclusion}

We conclude that 1) HMG-CoA reductase inhibitor alone is the cardioprotective effector of ischemic injury with or without either ACE inhibitor or AT1 receptor antagonist; 2) The protective effect caused by HMG-CoA reductase inhibitor alone is sufficient to activate myocardial metabolism against ischemic injury; 3) The effect of HMG-CoA reductase inhibitor is mediated by NO.

\section{Acknowledgements}

Pravastatin and temocaprilat were the kind gift of Sankyo Co., Ltd., Tokyo, Japan. CV-11974 was the kind gift of Takeda Chemical Industries, Ltd., Osaka, Japan.

\section{References}

1. Byington RP, Jukema JW, Salonen JT, et al: Reduction in cardiovascular events during pravastatin therapy: pooled analysis of clinical events of the pravastatin atherosclerosis intervention program. Circulation 1995; 92: 2419-2425.

2. Shepherd J, Cobbe SM, Ford I, et al: Prevention of coronary heart disease with pravastatin in men with hypercholesterolemia: West of Scotland Coronary Prevention Study Group. N Engl J Med 1995; 333: 1301-1307.

3. Sacks FM, Pfeffer MA, Moye LA, et al: The effect of pravastatin on coronary events after myocardial infarction in patients with average cholesterol levels. Cholesterol and Recurrent Events Trial Investigators. N Engl J Med 1996; 335: 1001-1009.

4. Kaesemeyer WH, Caldwell RB, Huang J, et al: Pravastatin sodium activates endothelial nitric oxide synthase independent of its cholesterol-lowering actions. J Am Coll Cardiol 1999; 33: 234-241.

5. Egashira $\mathrm{K}, \mathrm{Ni} \mathrm{W}$, Inoue $\mathrm{S}$, et al: Pravastatin attenuates cardiovascular inflammatory and proliferative changes in a rat model of chronic inhibition of nitric oxide synthesis by its cholesterol-lowering independent actions. Hypertens Res 2000; 23: 353-358.

6. McAlpine HM, Cobbe SM: Neuroendocrine change in acute myocardial infarction. Am J Med 1988; 84 (Suppl 3A): 61-66.

7. Ertl G, Kloner RA, Alexander RW, Braunwald E: Limitation of experimental infarct size by an angiotensin-converting enzyme inhibitor. Circulation 1982; 65: 40-48.

8. Liang C, Gavras H, Black J, Sherman LG, Hood WB: Renin-angiotensin system inhibition in acute myocardial infarction in dogs: effects on systemic hemodynamics, myocardial blood flow, segmental myocardial function and in- 
farct size. Circulation 1982; 66: 1249-1255.

9. Izumi H, Nakai T, Kano S, Hoshi K, Ichihara K: Effects of BIBR-277, an angiotensin II type 1 receptor antagonist, on stunned myocardium in dogs. Coron Artery Dis 1996; 7: 775-779.

10. Ertl G: Angiotensin converting enzyme inhibitors and ischaemic heart disease. Eur Heart J 1988; 9: 716-727.

11. Przyklenk K, Kloner RA: Relationships between structure and effects of ACE inhibitors: comparative effects in myocardial ischaemia/reperfusion injury. Br J Clin Pharmacol 1989; 28 (Suppl): 167S-175S.

12. Yoshiyama M, Kim S, Yamagishi H, et al: Cardioprotective effect of the angiotensin II type 1 receptor antagonist TCV-116 on ischemia-reperfusion injury. Am Heart $J$ 1994; 128 : 1-6.

13. Kawabata H, Ryomoto $\mathrm{T}$, Ishikawa K: Effect of angiotensin converting enzyme inhibitor and angiotensin II type 1 receptor antagonist on metabolism and contraction in ischemia-reperfused rabbit heart. Jpn Circ J 2000; 64: 276-282.

14. Linz W, Wohlfart P, Schölkens BA, Malinski T, Wiemer $\mathrm{G}$ : Interactions among ACE, kinins and NO. Cardiovasc Res 1999; 43: 549-561.

15. Clauser E, Curnow KM, Davies E, et al: Angiotensin II receptors: protein and gene structures, expression and potential pathological involvements. Eur J Endocrinol 1996; 134: 403-411.

16. Nio Y, Matsubara H, Murasawa S, Kanasaki M, Inada M: Regulation of gene transcription of angiotensin II receptor subtypes in myocardial infarction. J Clin Invest 1995; 95: 46-54.

17. Siragy HM, Carey RM: The subtype 2 (AT2) angiotensin receptor mediates renal production of nitric oxide in conscious rats. J Clin Invest 1997; 100: 264-269.

18. Gard JK, Kichura GM, Ackerman JJH: Quantitative ${ }^{31} \mathrm{P}$ nuclear magnetic resonance analysis of metabolite concentrations in Langendorff-perfused rabbit hearts. Biophys $J$ 1985; 48: 803-813.

19. Opie LH: The Heart: Physiology, Metabolism, Pharmacology and Therapy. London, Grune \& Stratton, 1984, pp351371.

20. Jennings RB, Reimer KA: Lethal myocardial ischemic injury. Am J Pathol 1981; 102: 241-255.

21. Wagner AH, Köhler T, Rückschloss U, et al: Improvement of nitric oxide-dependent vasodilation by HMG-CoA reductase inhibitors through attenuation of endothelial superoxide anion formation. Arterioscler Thromb Vasc Biol 2000; 20: 61-69.

22. Laufs U, Fata VL, Liao JK: Inhibition of 3-hydroxy-3methylglutaryl (HMG)-CoA reductase blocks hypoxia-mediated down-regulation of endothelial nitric oxide synthase. J Biol Chem 1997; 272: 31725-31729.

23. Laufs U, Fata VL, Plutzky J, et al: Upregulation of endothelial nitric oxide synthase by HMG CoA reductase inhibitors. Circulation 1998; 97: 1129-1135.

24. John S, Schlaich M, Langenfeld M, et al: Increased bioavailability of nitric oxide after lipid-lowering therapy in hypercholestrolemic patients: a randomized, placebocontrolled, double-blind study. Circulation 1998; 98: 211-216.
25. Masini E, Salvemini D, Ndisang JF, et al: Cardioprotective activity of endogenous and exogenous nitric oxide on ischemia reperfusion injury in isolated guinea pig hearts. Inflamm Res 1999; 48: 561-568.

26. Hotta Y, Otsuka-Murakami H, Fujita M, et al: Protective role of nitric oxide synthase against ischemia-reperfusion injury in guinea pig myocardial mitochondria. Eur J Pharmacol 1999; 380: 37-48.

27. Nakanishi K, Vinten-Johansen J, Lefer DJ, et al: Intracoronary L-arginine during reperfusion improves endothelial function and reduces infarct size. Am J Physiol 1992; 263: H1650-H1658.

28. Benjamin IJ, McMillan DR: Stress (heat shock) proteins: molecular chaperones in cardiovascular biology and disease. Circ Res 1998; 83: 117-132.

29. Vegh A, Szekeres L, Parratt J: Preconditioning of the ischaemic myocardium: involvement of the L-arginine nitric oxide pathway. Br J Pharmacol 1992; 107: 648-652.

30. Kawabata H, Ryomoto $\mathrm{T}$, Ishikawa K: Role of cardiac ATP-sensitive $\mathrm{K}^{+}$channels induced by HMG CoA reductase inhibitor in ischemic rabbit heart. Hypertens Res 2001; 24: 573-577.

31. Timmermans PBMWM, Wong PC, Chiu AT, et al: Angiotensin II receptors and angiotensin II receptor antagonists. Pharmacol Rev 1993; 45: 205-251.

32. Brown K: Angiotensin receptors are implicated in the mechanism of mas action. Trends Pharmacol Sci 1989; 10: 87-89.

33. Nishizuka $\mathrm{Y}$ : The family of protein kinase $\mathrm{C}$ for signal transduction. JAMA 1989; 262: 1826-1833.

34. Berridge MJ: Inositol, triphosphate, calcium, lithium, and cell signaling. JAMA 1989; 262: 1834-1841.

35. Schölkens BA, Linz W: Local inhibition of angiotensin II formation and bradykinin degradation in isolated hearts. Clin Exp Hypertens A 1988; 10: 1259-1270.

36. Kitakaze M, Node K, Takashima S, Minamino T, Kuzuya T, Holi M: Cellular mechanisms of cardioprotection afforded by inhibitors of angiotensin converting enzyme in ischemic hearts: role of bradykinin and nitric oxide. Hypertens Res 2000; 23: 253-259.

37. Timmermans PBMWM: Angiotensin II receptor antagonists: an emerging new class of cardiovascular therapeutics. Hypertens Res 1999; 22: 147-153.

38. Hübner R, Högemann AM, Sunzel M, Riddell JG: Pharmacokinetics of candesartan after single and repeated doses of candesartan cilexetil in young and elderly healthy volunteers. J Hum Hypertens 1997, 11 (Suppl 2): S19-S25.

39. Liu Y-H, Yang X-P, Sharov VG, et al: Effects of angiotensin-converting enzyme inhibitor and angiotensin II type 1 receptor antagonists in rats with heart failure: role of kinins and angiotensin II type 2 receptors. J Clin Invest 1997; 99: 1926-1935.

40. Wiemer G, Schölkens BA, Busse R, Wagner A, Heitsch H, Linz W: The functional role of angiotensin II-subtype AT2receptors in endothelial cells and isolated ischemic rat hearts. Pharm Pharmacol Lett 1993; 3: 24-27.

41. Jalowy A, Schulz R, Heusch G: AT1 receptor blockade in experimental myocardial ischemia/reperfusion. Basic Res Cardiol 1998, 93 (Suppl 2): 85-91.

42. Kawabata H, Ryomoto T, Ishikawa K: Cardioprotection 
with angiotensin converting enzyme inhibitor and angiotensin II type 1 receptor antagonist is not abolished by nitric oxide synthase inhibitor in ischemia-reperfused rabbit heart. Hypertens Res 2001; 24: 403-409.

43. Kawabata H, Ryomoto T, Ishikawa K: Role of cardiac ATP-sensitive $\mathrm{K}^{+}$channels induced by angiotensin II type 1 receptor antagonist on metabolism, contraction and relaxation in ischemia-reperfused rabbit heart. Jpn Circ J 2001; 65: $451-456$

44. Urata H, Healy B, Stewart RW, Bumpus M, Husain A: Angiotensin II-forming pathways in normal and failing human hearts. Circ Res 1990; 66: 883-890.

45. Hirakata H, Fouad-Tarazi FM, Bumpus M, Khosla M: Angiotensin and the failing heart. Circ Res 1990; 66: 891-899.

46. Okunishi H, Oka Y, Shiota N, Kawamoto T, Song K, Miyazaki M: Marked species-difference in the vascular angiotensin II-formong pathways: humans versus rodents. Jpn J Pharmacol 1993; 62: 207-210.

47. Schunkert $\mathrm{H}$, Ingelfinger $\mathrm{J} \mathrm{R}$, Hirsch $\mathrm{A} \mathrm{T}$, et al: Feedback regulation of angiotensin converting enzyme activity and mRNA levels by angiotensin II. Circ Res 1993; 72: 312-318. 